\title{
Nowe spojrzenie na nocną napadową hemoglobinurię
}

\author{
Novel insight into paroxysmal nocturnal hemoglobinuria
}

\author{
Agnieszka Piekarska ${ }^{1}$, Justyna Spychalska ${ }^{2}$ \\ ${ }^{1}$ Klinika Hematologii i Transplantologii, Gdański Uniwersytet Medyczny, Gdańsk \\ ${ }^{2}$ Zakład Immunologii Hematologicznej i Transfuzjologicznej, Instytut Hematologii i Transfuzjologii, Warszawa
}

\begin{abstract}
Streszczenie
Nocna napadowa hemoglobinuria (PNH) należy do tak zwanych chorób sierocych. Jest wywotana nabytym defektem klonalnym krwiotwórczej komórki macierzystej. Defekt ten polega na niedoborze lub braku na komórkach potomnych biatek btonowych zwiazanych z kotwica glikozylofosfatydyloinozytolu, w tym inhibitorów dopetniacza CD55 i CD59, będacym skutkiem mutacji w genie PIGA. $W$ efekcie u pacjentów dochodzi do ciagtej hemolizy zwiazanej z niekontrolowana aktywacja dopetniacza. Najczestsza przyczyna chorobowości i śmiertelności w tej chorobie sa powiktania zakrzepowo-zatorowe. W Polsce, ze względu na brak możliwości stosowania przeciwciata hamujacego uktad dopetniacza - ekulizumabu (leku zarejestrowanego do leczenia chorych z hemoliza i wysokq aktywnościa choroby), postępowanie terapeutyczne sprowadza sie do przetaczania koncentratu krwinek czerwonych, profilaktyki przeciwzakrzepowej i przeszczepiania allogenicznych krwiotwórczych komórek macierzystych u osób majacych zgodnego dawce. W pracy przedstawiono patomechanizm ztożonych zaburzeń obserwowanych w PNH ze szczególnym uwzglęnieniem powiktań zakrzepowo-zatorowych oraz omówiono wspótczesne wytyczne postępowania diagnostycznego i terapeutycznego.
\end{abstract}

Słowa kluczowe: nocna napadowa hemoglobinuria, hemoliza, zakrzepica, ekulizumab

Hematologia 2015; 6, 3: 278-292

\begin{abstract}
Paroxysmal nocturnal hemoglobinuria (PNH) is caused by the acquired clonal defect of hematopoietic stem cell and belongs to the "orphan diseases". This defect is associated with a lack or deficiency of the membrane glycosylphosphatidylinositol-anchored proteins on the surface of the progeny, including complement inhibitors CD55 and CD59, the result of mutation of the PIGA gene. Patients experience chronic hemolysis as the consequence of uncontrolled complement activation. Thrombotic complications are the most common reason of morbidity and mortality. Currently in Poland, due to no access to eculizumab (monoclonal antibody inhibiting the complement and registered to the treatment of PNH patients with hemolysis and the high disease activity), the therapy consists of packed red blood cells transfusions, anticoagulant prophylaxis and allogeneic hematopoietic stem cell transplantation when a matched donor is available. We present the pathomechanism of complex abnormalities observed in PNH including thrombotic complications as well as modern diagnostic and therapeutic guidelines.
\end{abstract}

Key words: paroxysmal nocturnal hemoglobinuria, hemolysis, thrombosis, eculizumab

Hematologia 2015; 6, 3: 278-292

Adres do korespondencji: Agnieszka Piekarska, Klinika Hematologii i Transplantologii, Gdański Uniwersytet Medyczny, ul. Dębinki 7, 80-952 Gdańsk, tel. 5834922 30, faks 5834922 33, e-mail: babajaga@gumed.edu.pl 


\section{Wprowadzenie}

Nocna napadowa hemoglobinuria (PNH, $p a$ roxysmal nocturnal hemoglobinuria) to nabyty defekt klonalny krwiotwórczej komórki macierzystej, którego objawy wynikają $z$ niedoboru lub braku na komórkach potomnych białek błonowych związanych $z$ kotwica glikozylofosfatydyloinozytolu (GPI, glycosylphosphatidylinositol), w tym inhibitorów dopełniacza CD55 i CD59. Należy do tak zwanych chorób sierocych, $z$ zapadalnością szacowaną na około 1,3/mln/rok [1]. Nocna napadowa hemoglobinuria jest rozpoznawana w każdej grupie wiekowej, przeważają jednak osoby około 30. roku życia [2]. $Z$ historycznych danych wynika, że około $35 \%$ pacjentów umierało $\mathrm{w}$ ciągu 5 lat od rozpoznania [3]. Najczęstszą przyczyną chorobowości i śmiertelności są powikłania zakrzepowo-zatorowe [4-6]. Występowanie PNH w Polsce jest $z$ pewnością niedoszacowane, częściowo ze względu na podstępny przebieg kliniczny, ale także dezinformującą nazwę choroby, wskazującą na jedynie niewielki fragment jej obrazu klinicznego. Hemoliza u pacjentów z PNH jest procesem przewlekłym, przebiegającym $24 \mathrm{~h} /$ dobę, stopniowo wyniszczającym, o trudnych do przewidzenia i potencjalnie śmiertelnych powikłaniach. Z kolei zaostrzenia, objawiające się jako hemoglobinuria, są efektem gwałtownego nasilenia hemolizy wewnątrznaczyniowej. Przykładowo, zaostrzenia występujące $\mathrm{w}$ godzinach porannych są związane $z$ obniżeniem $\mathrm{pH}$ krwi, które nasila spontaniczny rozkład składowej C3, inicjując niekontrolowaną aktywację drogi alternatywnej dopełniacza (CAP, complement alternative pathway).

W Polsce, ze względu na brak możliwości stosowania przeciwciała hamującego układ dopełniacza - ekulizumabu (Soliris ${ }^{\circledR}$ ), leku zarejestrowanego do leczenia chorych $z$ hemolizą i wysoką aktywnością choroby, postępowanie terapeutyczne sprowadza się do przetaczania koncentratu krwinek czerwonych (kkcz), profilaktyki przeciwzakrzepowej i przeszczepiania allogenicznych krwiotwórczych komórek macierzystych (allo-HSCT, allogeneic hematopoietic stem cell transplantation) u osób mających zgodnego dawcę. W ostatnich latach usystematyzowano oraz udoskonalono wytyczne diagnostyczne oparte na cytofluorometrii oraz opublikowano wyniki wieloletnich obserwacji pacjentów leczonych ekulizumabem. W związku $z$ tym pojawiła się potrzeba przybliżenia złożoności zaburzeń obserwowanych w PNH, a także istotnej roli hamowania układu dopełniacza w ich opanowaniu oraz zapobieganiu i leczeniu powikłań.

\section{Podłoże molekularne i patofizjologia zaburzeń w PNH}

W większości przypadków podłożem molekularnym jest mutacja genu PIGA (phosphatidylinositol glycan class $A$ ) zlokalizowanego na krótkim ramieniu chromosomu X krwiotwórczej komórki macierzystej, dająca $\mathrm{w}$ rezultacie klon komórek potomnych wszystkich linii komórkowych obciążonych tym defektem [7-9]. Kazuistycznie dochodzi do rozwoju PNH w wyniku mutacji genów zlokalizowanych na innych chromosomach, wówczas mutacji muszą ulec oba chromosomy [10].

Gen PIGA koduje podjednostkę A enzymu odpowiadającego za początkowy etap syntezy GPI - „kotwicy” przytwierdzającej do powierzchni błony komórkowej wiele kluczowych białek, tak zwanych białek związanych z GPI (GPI-AP, GPI-anchored proteins). Niemożność zakotwiczenia GPI-AP prowadzi do ich niedoboru lub braku ekspresji na powierzchni. Najistotniejszymi dla patofizjologii PNH są białka CD55 i CD59 będące naturalnymi inhibitorami układu dopełniacza. Białko CD55, inaczej DAF (decay-accelerating factor), przyspieszając rozkład konwertaz $\mathrm{C} 3$, zapobiega opsonizacji krwinek przez składową C3b i jej pochodne (C3d). Natomiast CD59, znane również jako białko MIRL (membrane inhibitor of reactive lysis), blokując przyłączanie składowej $\mathrm{C} 9$ do $\mathrm{C} 5 \mathrm{~b}-\mathrm{C} 8$, nie dopuszcza do powstania tak zwanego kompleksu atakującego błonę (MAC, membrane attack complex). Istnieją również inne naturalne czynniki regulujące aktywność dopełniacza, $\mathrm{w}$ tym bezpośrednio związany $\mathrm{z}$ błoną komórkową CD46 (MCP, membrane cofactor protein), który występuje na większości komórek organizmu Z wyjątkiem krwinek czerwonych [11]. Z tego względu niedobór lub brak inhibitorów dopełniacza szczególnie dotyka potomne erytrocyty, czyniąc je podatnymi na wtórną do aktywacji dopełniacza hemolizę wewnątrznaczyniową i zewnątrznaczyniową. Za większość objawów klinicznych i powikłań choroby odpowiada hemoliza wewnątrznaczyniowa $[3,8,12,13]$, z towarzyszącą aktywacją płytek krwi (PLT, platelets) i komórek śródbłonka [4].

\section{Konsekwencje kliniczne przewlekłej hemolizy}

W wyniku lizy indukowanej powstaniem MAC $z$ wnętrza erytrocytów do krwi jest uwalniana duża ilość wolnej hemoglobiny (Hb), która jest toksyczna dla śródbłonka naczyń i działa prozapalnie. Aby uniknąć efektu cytotoksycznego, Hb jest wiązana 


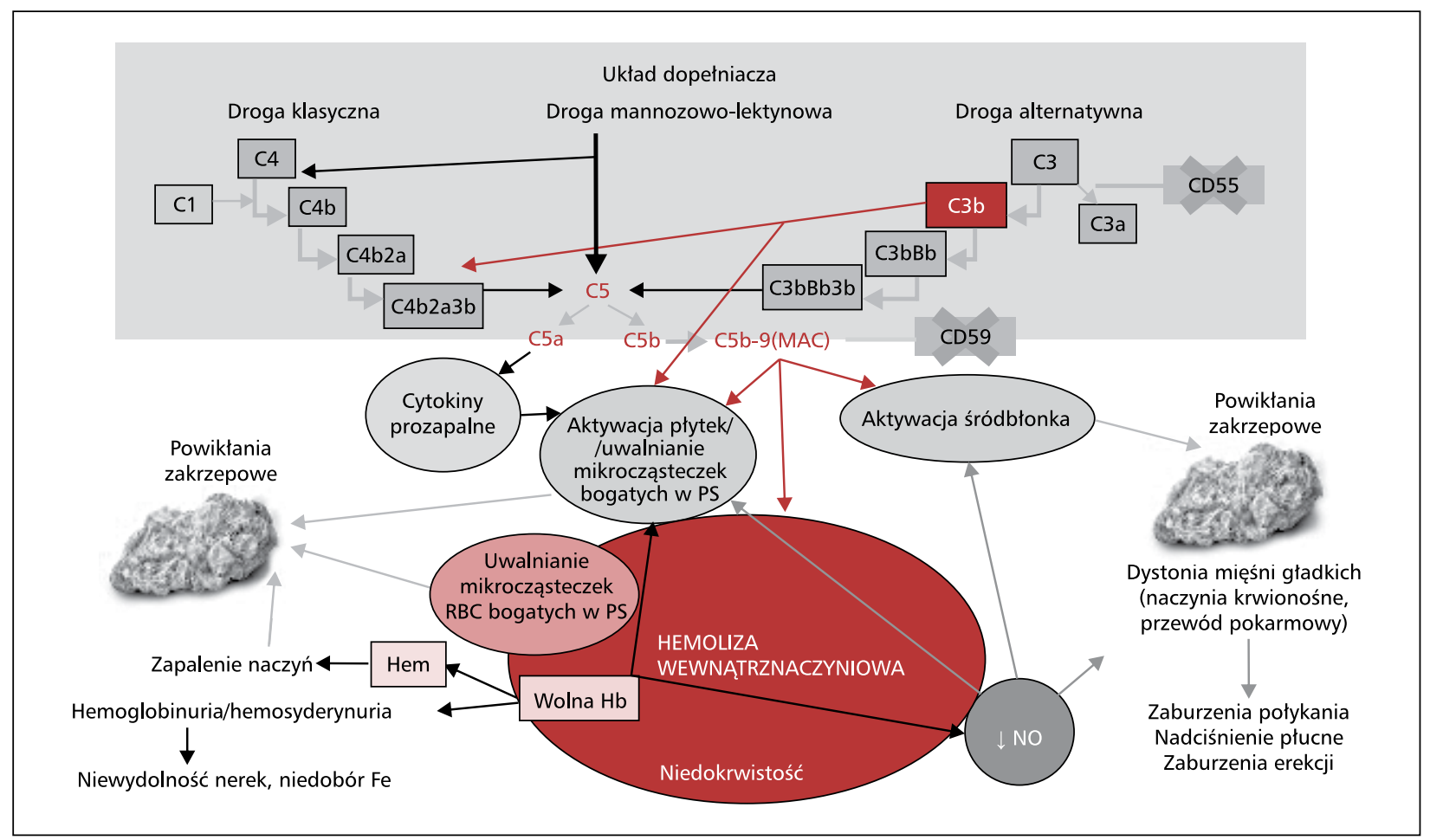

Rycina 1. Patofizjologia powikłań obserwowanych w nocnej napadowej hemoglobinurii — wybrane skutki niekontrolowanej aktywacji układu dopełniacza; MAC — kompleks atakujący błonę; PS — fosfatydyloseryna; RBC — krwinka czerwona; $\mathrm{Hb}$ - hemoglobina; Fe — żelazo; NO — tlenek azotu; $\downarrow$ - obniżenie

Figure 1. Pathophysiology of paroxysmal nocturnal hemoglobinuria complications — chosen consequences of uncontrolled compliment activation; MAC — membrane attack complex; PS — phosphatidylserine; Hb - hemoglobin; $\mathrm{Fe}$ - ferrum; NO — nitric oxide; RBC — red blood cel; $\downarrow$ - reduction

przez haptoglobinę (Hp) i w postaci dimerów usuwana na drodze fagocytozy za pośrednictwem receptora CD163 przez komórki żerne (monocyty, makrofagi). $Z$ kolei uwalniany $\mathrm{z}$ cząsteczki $\mathrm{Hb}$ toksyczny hem jest wiązany przez hemopeksynę (Hx, hemopexin). Kompleks hem-Hx jest usuwany z krążenia za pośrednictwem receptora CD91 na komórkach Kupffera i ulega degradacji w wątrobie. Zapasy Hp i Hx szybko się wyczerpują i dochodzi do kowalencyjnego połączenia utlenionej $\mathrm{Hb}$ z tlenkiem azotu (NO, nitric oxide), w wyniku którego powstają nieodwracalny kompleks methemoglobiny (metHb) i anion azotanowy. Wolna Hb ulega filtracji w nerkach i jest aktywnie reabsorbowana zwrotnie w proksymalnych kanalikach nerkowych, gdzie $z$ hemu jest uwalniane żelazo, które wiąże się $z$ hemosyderyną - toksycznie działającą na nerki i odpowiedzialną za objaw hemosyderynurii. Gdy dochodzi do wyczerpania zdolności aktywnej reabsorpcji wolnej $\mathrm{Hb}$ w kanalikach, pojawia się ona w moczu, powodując zjawisko hemoglobinurii.

Za większość powikłań obserwowanych w $\mathrm{PNH}$ odpowiada toksyczne działanie wolnej $\mathrm{Hb}$ i hemu oraz kompleksów z nimi związanych, a także zmniejszenie dostępności NO wynikające $z$ jego wiązania $\mathrm{z} \mathrm{Hb}$ oraz ograniczenia jego syntezy. Tlenek azotu pełni rolę czynnika rozkurczowego pochodzenia śródbłonkowego (EDRF, endothelium-derived relaxing factor), który reguluje napięcie mięśni gładkich naczyń; jest wytwarzany $z$ argininy w obrębie śródbłonka naczyń. W procesie hemolizy $z$ erytrocytów uwalnia się również arginaza - enzym, który przekształca argininę w ornitynę i tym samym zmniejsza ilość substratu do odtworzenia puli NO [14]. Niedobór NO jest więc bezpośrednio związany z nasileniem hemolizy i liniowo koreluje ze zwiększeniem aktywności dehydrogenazy mleczanowej (LDH, lactate dehydrogenase) w osoczu — markera aktywności hemolizy [15] (ryc. 1).

\section{Powikłania zakrzepowo-zatorowe}

Cytując Luzzatto i wsp. [5], PNH jest najbardziej podstępnym stanem nabytej trombofilii spośród znanych w medycynie. Zakrzepica to najczęstsza przyczyna zgonów w $\mathrm{PNH}$, szacowana na 40-67\%, natomiast $29-44 \%$ pacjentów doświadcza 
Tabela 1. Identyfikacja pacjentów obciążonych wysokim ryzykiem nocnej napadowej hemoglobinurii

Table 1. Recognition of patients with a high risk of paroxysmal nocturnal hemoglobinuria

\begin{tabular}{|c|c|c|c|}
\hline Hemoliza wewnątrznaczyniowa & & Dysfunkcja szpiku kostnego & Niewyjaśniona \\
\hline$\uparrow \mathrm{LDH}, \uparrow$ retikulocytoza, $\downarrow$ haptoglobina & AA & Cytopenia & $\begin{array}{l}\text { Tętnicza } \\
\text { lub żylna }\end{array}$ \\
\hline $\begin{array}{l}\text { Dodatkowo jedno z poniższych: } \\
\text { - niedokrwistość hemolityczna z ujemnym BTA } \\
\text { - hemoglobinuria/hemosyderynuria } \\
\text { - dysfunkcja nerek } \\
\text { - bóle jamy brzusznej; dysfagia; zaburzenia erekcji; zmęczenie }\end{array}$ & & $\begin{array}{l}\text { Dodatkowo jedno z poniższych: } \\
\text { - cechy hemolizy; hipoplas- } \\
\text { tyczny MDS; oporna } \\
\text { cytopenia; niedobór Fe } \\
\text { - cechy hemolizy; oporny na } \\
\text { leczenie; niedobór Fe; brak } \\
\text { odpowiedzi na leczenie; } \\
\text { towarzysząca zakrzepica }\end{array}$ & $\begin{array}{l}\text { Dodatkowo } \\
\text { jedno z poniż- } \\
\text { szych: } \\
\text { - nietypowa } \\
\text { lokalizacja*; } \\
\text { młody wiek; } \\
\text { cechy } \\
\text { hemolizy; } \\
\text { cytopenia; } \\
\text { brak lub } \\
\text { nieadekwat- } \\
\text { na odpo- } \\
\text { wiedź na an- } \\
\text { tykoagulanty }\end{array}$ \\
\hline
\end{tabular}

Wskazane wykonanie badania cytometrycznego z krwi obwodowej

*Żyły wątrobowe (zespół Budda-Chiariego), inne żyły wewnątrzbrzuszne (wrotna, śledzionowa, trzewne), naczynia/zatoki mózgowe, żyły skórne; $\uparrow$ — zwiększenie; $\downarrow$ obniżenie; LDH (lactate dehydrogenase) — dehydrogenaza mleczanowa; AA (aplastic anemia) — anemia aplastyczna; MDS (myelodysplastic syndrome) - zespół mieloobnizenie; LDH (lactate dehydrogenase) - dehydrogenaza mleczanowa; AA (aplastic anemia) — anemia
dysplastyczny; BTA (direct antiglobulin test) - bezpośredni test antyglobulinowy; Fe (ferrum) - żelazo

przynajmniej jednego incydentu zakrzepowo-zatorowego [2-4, 6, 13, 16]. Współczynnik 4-letniego przeżycia chorego $z$ zakrzepicą przy rozpoznaniu wynosi około $40 \%$ [2], a względne ryzyko zgonu zwiększa się 5 do 15,7 razy [16]. Wskaźniki występowania zakrzepicy w PNH są z pewnością niedoszacowane ze względu na częsty bezobjawowy przebieg. Na przykład, mikrozatorowość płucna jest wykrywana czułymi technikami obrazowymi u 6 na 10 chorych na PNH, bez poprzedzającego wywiadu zakrzepowo-zatorowego. Podobnie u 2 na 10 pacjentów stwierdzono uszkodzenie mięśnia sercowego w przebiegu subklinicznie przebiegających epizodów zakrzepowych, co $z$ czasem prowadzi do niewydolności serca [17]. Wystąpienie zakrzepicy jest nieprzewidywalne i może się rozwinąć w przypadku istnienia niewielkiego klonu PNH na poziomie $10 \%$ lub niższym. Ryzyko powikłań zakrzepowo-zatorowych znacząco jednak wzrasta przy wielkości klonu $z$ defektem GPI przekraczającym 50\% granulocytów i aktywnej hemolizie $z$ wartością $L D H$ 1,5 razy powyżej górnej granicy normy [18].

Zakrzepica może dotyczyć zarówno naczyń żylnych, jak i tętniczych; najczęstsza lokalizacja to naczynia wewnątrzbrzuszne i krążenie mózgowe [19]. Zakrzepica żyły wątrobowej (zespół Budda-Chiariego) dotyka 7,5-25\% pacjentów z PNH, prowadząc do niewydolności wątroby. Często towarzyszy jej zakrzepica naczyń trzewnych. Opisywane są również incydenty niedokrwienia jelit wskutek zajęcia naczyń krezkowych. Zakrzepica w naczyniach trzewnych najczęściej objawia się bólami jamy brzusznej, ale może też przebiegać bezobjawowo $[4,20]$. $Z$ kolei najczęstszym powikłaniem neurologicznym o bardzo wysokiej śmiertelności jest zakrzepica w zatoce strzałkowej, $z$ częstym wtórnym ukrwotocznieniem. Możliwe są też inne lokalizacje w obrębie naczyń żylnych i tętniczych mózgowia [21]. Natomiast opisywane w literaturze zakrzepice w obrębie naczyń skórnych przebiegają z powstawaniem bolesnych ogniskowych przebarwień [22].

Według Hill i wsp. [4] diagnostykę trombofilii należy uzupełnić o badania w kierunku PNH w przypadku niewytłumaczalnej zakrzepicy u osoby młodej, nietypowej lokalizacji (naczynia wewnątrzbrzuszne, mózgowe, skórne), obecnych wskaźników hemolizy lub jakiejkolwiek cytopenii (tab. 1).

Patofizjologia powikłań zakrzepowo-zatorowych w PNH jest wieloczynnikowa i składają się na nią przede wszystkim wewnętrzne powiązania między układem dopełniacza a kaskadą krzepnięcia, hemolizy wewnątrznaczyniowej indukowanej niekontrolowaną aktywacją dopełniacza, aktywacji PLT i śródbłonka, obniżonej dostępności NO, uwolnienia mediatorów prozapalnych oraz zaburzeń w systemie fibrynolizy.

W wyniku niedoboru białka CD59 dochodzi do gromadzenia się kompleksów MAC na powierzchni PLT, w wyniku czego następują ich zmiany morfologiczne - uwalnianie pęcherzyków błonowych zawierających MAC, utrata asymetrii błony i zwiększanie ekspresji białek związanych $z$ aktywacją. Fosfatydyloseryna (PS, phosphatidylserine) 
obecna na mikrocząstkach płytkowych może być miejscem wiązana kompleksów protrombinazy i tenazy, prowadząc tym samym do zwiększonej generacji trombiny. Aktywowane PLT mogą również oddziaływać $z$ neutrofilami, wywołując zwiększone uwalnianie $z$ nich proteaz serynowych i nukleosomów, które synergistycznie aktywują czynnik X. Niedobór NO prowadzi do zwiększonego powstawania wolnych rodników tlenowych, a stres oksydacyjny i generacja trombiny wtórnie aktywują PLT. W ten sposób aktywacja PLT jest włączona w występującą u chorego na PNH sieć sprzężeń zwrotnych. W związku z ciągłym pobudzaniem drogi alternatywnej dopełniacza (poprzez P-selektynę) oraz inicjację aktywacji klasycznej drogi dopełniacza (poprzez pochodzący z PLT siarczan chondroityny) mogą podtrzymywać błędne koło lub nasilać zjawiska prokoagulacyjne. Monitorując chorego na $\mathrm{PNH}$, należy zwracać uwage na liczbę PLT, ponieważ jej nagłe obniżenie budzi podejrzenie rozwoju epizodu zakrzepowego.

Hemoliza wewnątrznaczyniowa w wielu mechanizmach prowadzi do stanu nadkrzepliwości. W wyniku rozpadu erytrocytów uwalniają się mikrocząstki błonowe bogate w PS [23]. Wolna $\mathrm{Hb}$ oraz niedobór NO powodują nasilenie adhezji i agregacji PLT. Hem działa prozapalnie i ma zdolność indukowania zapalenia żył, a jego dalsze przemiany uwalniają toksyczne rodniki żelaza, które potem uczestniczą w katalizowaniu reakcji powstawania rodników tlenu, uszkadzających błony lipidowe. Wolna $\mathrm{Hb}$ hamuje aktywność metaloproteinazy rozkładającej multimery czynnika von Willebranda (ADAMTS13, metalloprotease cleaving high molecular weight multimers of von Willebrand factor) oraz bezpośrednio powoduje dysfunkcję śródbłonka, jego aktywację i uwalnianie mikrocząstek. Dysfunkcja śródbłonka prowadzi też do zwiększenia produkcji czynnika tkankowego (TF, tissue factor), uwalniania dużych multimetrów czynnika von Willebranda (vWF, von Willebrand factor) i czynnika VIII.

Niedobór NO, poza wpływem na PLT, dodatkowo wykazuje efekt wazokonstrykcyjny (zwiększając napięcie mięśni gładkich), nasila proliferację śródbłonka oraz zwiększa ekspresję P-selektyny. Tlenek azotu może również oddziaływać na układ krzepnięcia - jego niedobór poprzez aktywację czynnika XIII nasila stabilność skrzepu, a przez zwiększanie poziomu kompleksów trombina-antytrombina i produktów rozpadu fibryny może nasilić odkładanie fibryny i tworzenie skrzepów.

Kolejnym elementem, bezpośrednio związanym $z$ brakiem kotwic GPI, są niedobory CD87, receptora aktywatora plazminogenu (u-PAR, urokinase-type plasminogen activator receptor), proteinazy 3 (PR3), inhibitora szlaku zależnego od czynnika tkankowego (TFPI, tissue factor pathway inhibitor) oraz siarczanu heparanu. Siarczan heparanu pośredniczy w wiązaniu antytrombiny do komórek śródbłonka, należy do GPI-AP i jego ekspresja ulega obniżeniu pod wpływem cytokin prozapalnych - interleukiny 1 (IL-1) oraz czynnika martwicy nowotworów $\alpha$ (TNF $\alpha$, tumor necrosis factor $\alpha$ ). Niedobór u-PAR na powierzchni komórek oraz nadmiar w osoczu jego formy rozpuszczalnej w połączeniu $z$ obecnością mikrocząstek $z$ erytrocytów może osłabiać fibrynolizę. $Z$ kolei TFPI jest jedynym fizjologicznym inhibitorem początkowego etapu krzepnięcia uwalnianym przez śródbłonek, ale obecnym również na powierzchni monocytów i PLT, pośrednio zakotwiczonym przez GPI. Uważa się, że zmniejszona ekspresja TFPI na powierzchni, a także obniżona aktywność wywołana działaniem cytokin prozapalnych, może odpowiadać za stan trombofilii u chorych na PNH. Natomiast PR3 nie jest GPI-AP, ale jej obecność na błonie komórkowej pośrednio zależy od CD177 (GPI-AP); PR3 obniża aktywację PLT indukowaną trombiną poprzez rozkładanie receptora dla trombiny.

Ważnym elementem patofizjologii powikłań zakrzepowych w PNH jest - zależne od niekontrolowanej aktywacji dopełniacza, a niezależne od hemolizy - uwalnianie dużej ilości składowej C5a, działającej prozapalnie poprzez IL-6, IL-8 i TNF $\alpha$ i prozakrzepowo poprzez aktywacje śródbłonka, oraz IL-6, która ułatwia formowanie trombiny i hamuje aktywność ADAMTS13. Formowanie MAC i działanie C5a wpływa również na monocyty i granulocyty. W wyniku ich aktywacji zwiększa się ekspresja TF i inhibitora aktywatora plazminogenu (PAI, plasminogen activator inhibitor). Stan trombofilii w PNH może również zależeć od obniżonego u niektórych pacjentów stężenia białka S, krążącego w kompleksach $z$ białkiem wiążącym $\mathrm{C} 4 \mathrm{~b}$, oraz nabytej oporności na aktywowane białko $\mathrm{C}$.

Ścisła zależność między kaskadą krzepnięcia i układem dopełniacza doprowadziła do stworzenia czwartej drogi aktywacji dopełniacza (ryc. 2). Trombina bez udziału konwertaz ma zdolność aktywowania i rozkładania składowej C3 i C5 [24]. W ten sposób zakrzepica w mechanizmie błędnego koła nasila aktywację dopełniacza. To zjawisko może tłumaczyć zwiększone występowanie kolejnych powikłań zakrzepowo-zatorowych po pierwszym incydencie, mimo stosowania terapii przeciwkrzepliwej. 


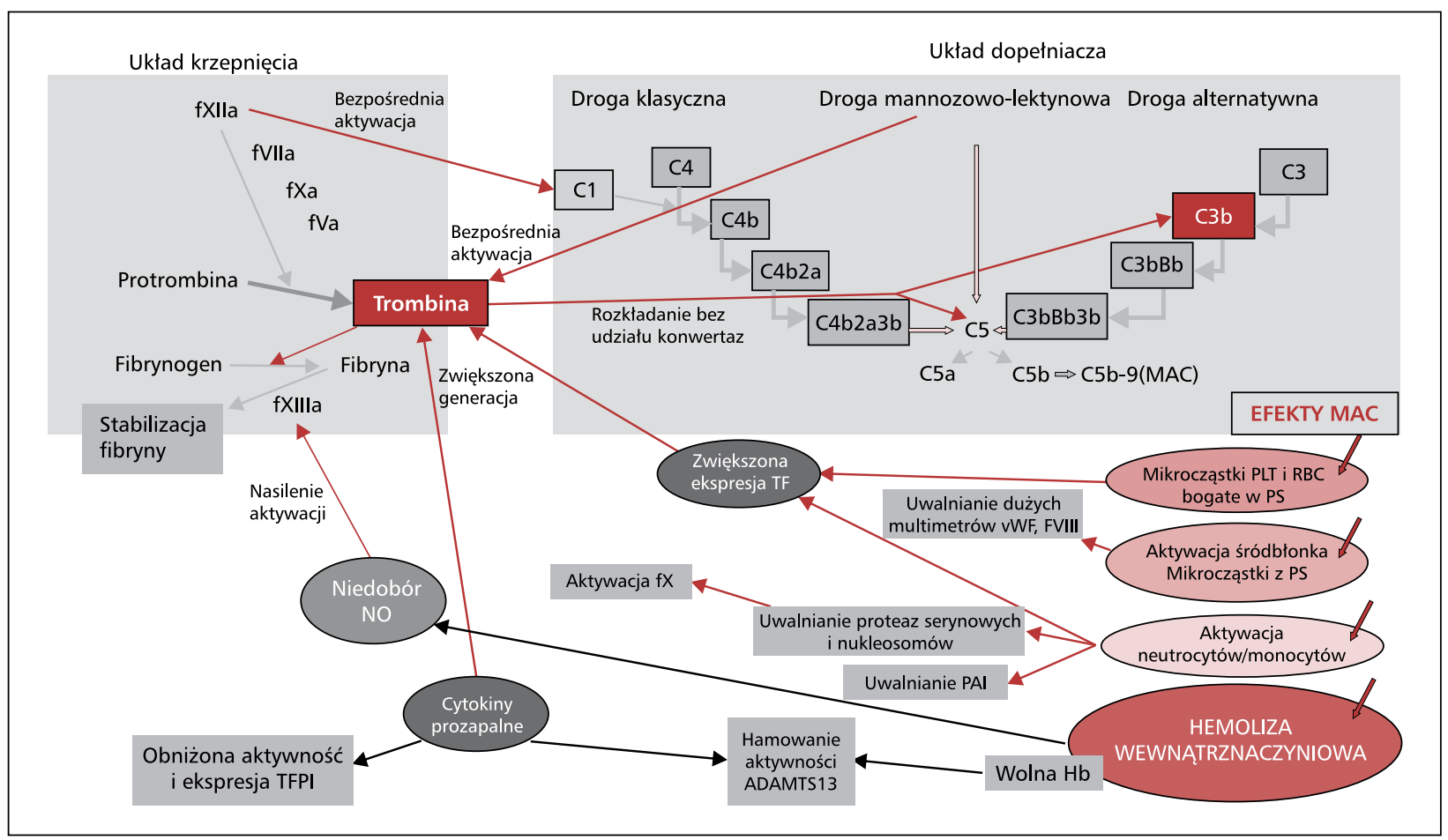

Rycina 2. Patomechanizm powikłań zakrzepowo-zatorowych w nocnej napadowej hemoglobinurii — bliskie współzależności między kaskadą układu krzepnięcia a układem dopełniacza i hemolizą; fXIla — czynnik XII aktywowany; fVIla — czynnik VII aktywowany; fXa — czynnik X aktywowany; fVa — czynnik V aktywowany; MAC — kompleks atakujący błonę; fXIIla — czynnik XIII aktywowany; TF — czynnik tkankowy; vWF — czynnik von Willebranda; fVIII — czynnik VIII; PLT — płytki krwi; RBC — krwinka czerwona; PS — fosfatydyloseryna; NO — tlenek azotu; fX — czynnik X; PAI — inhibitor aktywatora plazminogenu; TFPI — inhibitor szlaku zależnego od czynnika tkankowego; ADAMTS13 — metaloproteinaza rozkładająca multimery $\mathrm{VWF} ; \mathrm{Hb}$ - hemoglobina

Figure 2. Pathomechanism of nocturnal hemoglobinuria thrombotic complications - close relationship between the coagulation cascade and the complement pathway and hemolysis; fXIla - factor XII activated; fVIla - factor VII activated; fXa - factor X activated; fVa - factor V activated; MAC - membrane attack complex; fXIIla - factor XIII activated; TF — tissue factor; vWF — von Willebrand factor; fVIII — factor VIII; PLT — platelets; RBC — red blood cells; PS - phosphatidylserine; NO — nitric oxide; $f X$ — factor X; PAI — plasminogen activator inhibitor; TFPI — TF pathway inhibitor; ADAMTS 13 - metalloprotease cleaving high molecular weight multimers of $\mathrm{vWF}$; $\mathrm{Hb}$ - hemoglobin

\section{Niewydolność nerek}

Około 64\% chorych na PNH cierpi na przewlekłą chorobę nerek (CKD, chronic kidney disease), która odpowiada za 8-18\% zgonów [18, 25]. Czynnikami prowadzącymi do uszkodzenia nerek są hemosyderyna odkładająca się w kanalikach, przewlekła hemosyderynuria, hemoglobinuria oraz zaburzenia przepływu krwi przez nerki w wyniku zmniejszenia dostępności NO oraz mikrozakrzepicy naczyń nerkowych. U wielu pacjentów CKD przebiega $z$ zespołem Fanconiego (zaburzenia absorpcji zwrotnej drobnocząsteczkowych substancji np. wody, aminokwasów, glukozy, niektórych jonów) [14]. Jedynie zastosowanie ekulizumabu daje szansę na stabilizację, a nawet poprawę funkcji nerek, szczególnie we wcześniejszych stadiach CKD [25].

\section{Nadciśnienie płucne}

Około 66\% chorych na PNH zgłasza duszność, której przyczyną może być między innymi nadciśnienie płucne, potwierdzane $w$ badaniach u przynajmniej $47 \%$ chorych. Podłożem rozwoju nadciśnienia płucnego jest indukowana dopełniaczem hemoliza wewnątrznaczyniowa powodująca ekspozycję na wolną $\mathrm{Hb}$ oraz obniżająca stężenie NO. Wywołuje to dysfunkcję śródbłonka naczyń, wzrost napięcia mięśniówki gładkiej oraz waskulopatię. Dodatkowym czynnikiem prowadzącym do rozwoju nadciśnienia płucnego jest, często przebiegająca podklinicznie, mikrozatorowość płucna $[17,26]$. W terapii pacjentów skuteczny okazuje się ekulizumab. Przed terapią u prawie połowy pacjentów stężenie $\mathrm{N}$-końcowego propeptydu natriuretycznego typu B 
(NT-proBNP, $N$-terminal natriuretic propeptide type B) jest podwyższone oraz występuje dysfunkcja prawego przedsionka wtórna do nadciśnienia płucnego. W ciągu 2 tygodni od włączenia leczenia, poza znaczącym ograniczeniem hemolizy i wzrostem stężenia NO, zaobserwowano zmniejszenie napięcia wazomotorycznego, ograniczenie duszności oraz obniżenie stężenia NT-proBNP [15].

\section{Inne objawy i jakość życia pacjentów}

Do innych objawów PNH rzutujących na jakość życia pacjentów należą: zmęczenie (80\%), bóle głowy (63\%), zaburzenia erekcji (38\% płci męskiej), silne bóle jamy brzusznej oraz zaburzenia połykania. Zaburzenia erekcji i połykania są związane $z$ dystonią mięśni gładkich [18].

\section{Klasyfikacja z uwzględnieniem historii naturalnej choroby}

Na postawie obrazu klinicznego i wielkości klonu PNH International PNH Interest Group wyodrębnia trzy postacie choroby [27]. W podtypie klasycznym stwierdza się dużą populację komórek $z$ defektem GPI-AP (najczęściej > 50\% komórek krwi obwodowej), z czym wiąże się dominacja w obrazie klinicznym powikłań związanych $z$ hemolizą wewnątrznaczyniową oraz występowanie epizodów hemoglobinurii. W postaci tej, przynajmniej wyjściowo, oprócz hiperplazji linii czerwonokrwinkowej nie obserwuje się istotnych zaburzeń w szpiku. Niedokrwistości hemolitycznej może jednak towarzyszyć neutropenia i/lub małopłytkowość.

U pacjentów $z$ drugą postacią, w której klon PNH towarzyszy niewydolności szpiku, hemoliza przebiega lagodniej; przeważają objawy związane $z$ cytopeniami w przebiegu choroby podstawowej, na przykład niedokrwistości aplastycznej (AA, aplastic anemia) lub zespołu mielodysplastycznego (MDS, myelodysplastic syndrome). Klon PNH stanowi najczęściej 25-50\% komórek krwi obwodowej.

W subklinicznej postaci PNH, ze względu na niewielki odsetek komórek GPI ujemnych (GPI-) (najczęściej < 1\%), nie obserwuje się cech hemolizy, dominują natomiast objawy niewydolności szpiku. Jednak klon może się rozwinąć, prowadząc do pojawienia się klinicznie istotnej hemolizy. W przypadku AA $z$ towarzyszącym klonem PNH po skutecznej terapii immunoablacyjnej może dojść do regeneracji hematopoetycznej klonem PNH i przejścia $z$ podtypu subklinicznego do postaci klasycznej [13, 28-31].

Niewyjaśniony pozostaje mechanizm osiagania dominacji krwiotwórczej komórki macierzystej ze zmutowanym genem PIGA nad prawidłowymi komórkami macierzystymi. Jeśli do mutacji dochodzi w komórkach na wyższym poziomie rozwoju, na przykład jednostek tworzących kolonie (CFU, colony forming unit), jak ma to miejsce u zdrowych osób i niektórych pacjentów z MDS, to ze względu na brak możliwości samoodtwarzania defektywny klon zanika [7, 32, 33]. W związku z częstym występowaniem klonu PNH u chorych na AA zaczęto od poszukiwania związku między tymi dwiema chorobami. Według wczesnych teorii komórki pozbawione kotwicy GPI unikają ataku immunologicznego, ponieważ obiektem tego ataku mogą być białka GPI-AP, ale nie znaleziono na to dowodu $[34,35]$. Zgodnie $z$ drugą teorią istnieje dodatkowa, choć dotąd niezidentyfikowana, mutacja lub dysregulacja epigenetyczna, dzięki której komórki klonu PNH mają przewagę proliferacyjną [30, 36]. W myśl trzeciej teorii do dominacji komórek macierzystych GPI(-) dochodzi dzięki ich oporności na apoptozę. Możliwe jest również, że komórki krwiotwórcze GPI-AP(+) u pacjentów z PNH mają obniżone możliwości przeżycia $\mathrm{w}$ „nieprzyjaznym" środowisku związanym $z$ obecnością klonu GPI-AP(-). Istnieje również model „neutralnej ewolucji”, według której w sposób naturalny klon PNH zyskuje przewagę $\mathrm{w}$ ubogokomórkowym szpiku kostnym [37]. W kolejnej teoria „pogodzono" teorię pierwszą i trzecią, proponując, że preferencyjne przeżycie klonu PNH jest związane $z$ niedoborem białek indukowanych stresem ULBP 1 i ULBP2 (UL16-binding protein), które należą do GPI-AP. Są one między innymi receptorami dla komórek naturalnej cytotoksyczności (NK, natural killer), za pośrednictwem których dochodzi do apoptozy komórek docelowych. W badaniach doświadczalnych udowodniono mniejszą wrażliwość klonu PNH na śmierć w mechanizmie apoptozy zależnej od komórek NK [34, 38]. Zaproponowano również teorię opartą na wykazanej zwiększonej mobilności i obniżonej adhezji krwiotwórczych komórek macierzystych/progenitorowych GPI(-), dzięki czemu klon $z$ defektem PNH może wypierać prawidłowe komórki krwiotwórcze i zasiedlać nisze w szpiku kostnym [39, 40].

\section{Diagnostyka}

The International Clinial Cytometry Society (ICCS) zaleca wykonywanie badań w kierunku PNH u dwóch grup chorych: 1) $\mathrm{z}$ wewnątrznaczyniową hemolizą $z$ ujemnym wynikiem bezpośredniego testu antyglobulinowego (BTA), której mogą towarzyszyć: granulocytopenia, trombocytopenia, 
zakrzepica żylna lub tętnicza (zwłaszcza występująca w nietypowych lokalizacjach), niewydolność nerek, epizody hemoglobinurii, dysfagii, bólów brzucha lub zaburzenia erekcji; 2) z niewyjaśnionymi cytopeniami oraz z rozpoznaniem AA, MDS, hipoplazji szpiku kostnego lub innej choroby związanej $z$ niewydolnością szpiku, nawet jeśli nie ma u nich oznak hemolizy [1, 41] (patrz tab. 1).

„Złotym standardem” w diagnostyce PNH jest obecnie cytometria przeplywowa [27]. Ze względu na duże różnice $\mathrm{w}$ stosowanych testach oraz częsty brak doświadczenia w interpretowaniu wyników zaistniała konieczność wprowadzenia w laboratoriach cytometrycznych ujednoliconych metod do oceny odsetka komórek GPI(-), zgodnych $z$ zaleceniami opublikowanymi przez ICCS $[1,42]$. Materiałem do badań jest krew obwodowa pobrana do probówki $z$ antykoagulantem (heparyna, kwas etylenodiaminotetraoctowy [EDTA, ethylenediaminetetraacetic acid] — inaczej kwas wersenowy), przechowywana i transportowana w warunkach chłodniczych.

Podstawą rozpoznania PNH powinny być dodatnie wyniki badań — niedoboru lub braku GPI na co najmniej dwóch liniach komórkowych. $\mathrm{W}$ pierwszej kolejności przeprowadzane są badania służące ocenie leukocytów. Zaleca się wykonanie testu na granulocytach w ciągu 48 godzin od pobrania próbki. W starszych próbkach zmniejsza się żywotność tych krwinek, a także niespecyficzne zwiększa się wiązanie przeciwciał, co znacząco utrudnia analizę. U niektórych pacjentów granulocytopenia uniemożliwia ich ocenę, wówczas podejmuje się próbę oceny monocytów. Nie zaleca się analizy limfocytów. Dopiero w przypadku wykrycia komórek GPI(-) w populacji granulocytów lub monocytów wykonuje się dodatkowy test na erytrocytach (badanie można wykonać do $7 \mathrm{dni}$ od pobrania materiału) [1].

Wprowadzenie do diagnostyki inaktywowanej aerolizyny znakowanej fluorescencyjnie (FLAER, fluorescein-labeled aerolysin), która swoiście wiąże się do cząsteczek GPI na leukocytach, zaowocowało nowym testem przesiewowym $[43,44]$. W cytometrze można wykryć granulocyty i monocyty FLAER(-), czyli pozbawione kotwic GPI. Test ten pozwala na identyfikację co najmniej $0,1 \%$ klonu PNH na granulocytach [45]. Przesiewowego testu FLAER nie zaleca się u chorych, u których występuje neutropenia związana $z$ AA, hipoplastycznym MDS lub innymi zaburzeniami w szpiku kostnym. Takie osoby poddaje się wieloparametrowym testom wysokoczułym pozwalającym na wykrycie 0,01\% komórek $\mathrm{z}$ niedoborem lub całkowitym brakiem kotwic GPI oraz GPI-AP [27, 46, 47]. Badania wysokoczułe polegają na jednoczesnym zastosowaniu FLAER oraz przeciwciał monoklonalnych skierowanych do białek związanych $z$ błoną za pomocą kotwic GPI (CD24, CD14, CD157) oraz przeciwciał skierowanych do markerów linii komórkowych (CD45, CD15, CD33, CD64). $\mathrm{W}$ wielu laboratoriach stosuje się 4-kolorową metodę $z$ zastosowaniem FLAER oraz przeciwciał anty-CD24, CD45 i CD15 do oceny granulocytów obojętnochłonnych oraz FLAER łącznie z przeciwciałami anty-CD14, CD45 i CD64 do oceny monocytów. Niektóre laboratoria oferują 5- lub 6-kolorową jednoczesną analizę granulocytów i monocytów [48, 49]. Erytrocyty są badane wysokoczułą metodą 2-kolorową $z$ zastosowaniem przeciwciał monoklonalnych skierowanych do białka CD59 (GPI-AP) oraz CD235a (glikoforyna A). Należy zaznaczyć, że na odsetek erytrocytów $z$ defektem GPI wpływają przetoczenia kkcz oraz hemoliza. W związku z tym można otrzymać wynik fałszywie ujemny [50, 51].

Wysokoczułe testy pozwalają na wykrycie komórek z prawidłową ekspresją kotwic GPI (typu I), komórek $z$ obniżoną ekspresją GPI (typu II) oraz $z$ całkowitym brakiem GPI (typu III), choć nie u wszystkich pacjentów występują komórki typu II. W sprawozdaniu powinna się znaleźć informacja o wykryciu oraz wartości odsetka komórek Z defektem PNH (komórek typu III lub sumy komórek typu II i III) w każdej badanej populacji. Interpretacja wyniku zależy od ilości komórek $z$ defektem: 1) w przypadku ponad $1 \%$ defekt opisuje się jako klon PNH, 2) w przypadku 0,1-1\% — jako nieznaczny klon PNH, 3) w przypadku 0,1\% lub mniej - jako nieliczne komórki $z$ defektem GPI (o fenotypie $\mathrm{PNH}$ ).

U każdego chorego $z$ nowo rozpoznaną $\mathrm{PNH}$, ze względu na możliwość ekspansji lub zaniknięcia klonu GPI(-), wskazane jest systematyczne monitorowanie jego wielkości w 1 . roku od momentu rozpoznania co 3-6 miesięcy, następnie co 6-12 miesięcy lub w przypadku występowania częstszych zaostrzeń hemolizy [1, 13, 30, 52]. Podczas terapii ekulizumabem pierwsze badania kontrolne należy wykonać 6 miesięcy po rozpoczęciu leczenia. Pacjenci po procedurze allo-HSCT również wymagają regularnych badań metodami wysokoczułymi $\mathrm{w}$ celu detekcji i monitorowania choroby resztkowej. Podobnie chorzy na AA powinni być badani na obecność klonu PNH metodą wysokoczułą przynajmniej raz w roku [41]. Natomiast nie ma konieczności ponawiania testów w kierunku PNH u chorych $\mathrm{z}$ niewyjaśnioną zakrzepicą, 
hemolizą lub hemoglobinurią, jeśli za pierwszym razem nie wykryto komórek GPI(-) [1].

Laboratoria zajmujące się diagnostyką $\mathrm{PNH}$ mogą korzystać $z$ testów zewnętrznej kontroli jakości, które obecnie oferują dwie instytucje: UK NEQAS (United Kingdom National External Quality Assesment Schemes) oraz CAP (College of American Pathologists). Ze względu na rzadkość choroby cenna jest również międzynarodowa wymiana doświadczeń w ramach kursów organizowanych przez ESCCA (European Society for Clinical Cell Analysis) i UK National Academy for Clinical Flow Cytometry oraz szkoleń prowadzonych przez laboratoria referencyjne [46].

\section{Leczenie}

Postępowanie terapeutyczne w dużej mierze zależy od manifestacji klinicznej choroby [6]. W przypadku asymptomatycznej obecności klonu PNH (zazwyczaj dotyczy to $<10 \%$ granulocytów GPI-) towarzyszącego zespołowi niewydolności szpiku działania powinny być ukierunkowane na leczenie cytopenii. W AA, zależnie od stopnia ciężkości choroby, wieku chorego i dostępności dawcy, wskazana jest immunoablacja lub allo-HSCT [53]. W przypadku klasycznej postaci PNH jedynymi metodami o udowodnionej skuteczności są allo-HSCT oraz blokowanie układu dopełniacza za pomocą przeciwciał monoklonalnych, na przykład ekulizumabu, TT30 [13, 52].

\section{Przeszczepienie allogenicznych}

krwiotwórczych komórek macierzystych

Przeszczepienie allogenicznych krwiotwórczych komórek macierzystych jest jedyną potencjalną metodą wyleczenia $z$ PNH. Preferowanym źródłem komórek krwiotwórczych do przeszczepienia jest szpik kostny [54-56]. Przeprowadzenie procedury allo-HSCT wiąże się jednak $z$ wysokim ryzykiem powikłań we wczesnym okresie potransplantacyjnym. Aktywacja śródbłonka naczyń i PLT oraz konsekwencje hemolizy wewnątrznaczyniowej predysponują u tej szczególnej grupy pacjentów do rozwoju choroby wenookluzyjnej (VOD, veno-occlusive disease) i ostrej niewydolności nerek. Dodatkowo istnieje ryzyko innych ciężkich, w tym śmiertelnych, powikłań, między innymi infekcji oraz ostrej i przewlekłej choroby przeszczep przeciw gospodarzowi (GvHD, graft versus host disease). Według danych EBMT (European Society of Blood and Marrow Transplantation) 5-letnie przeżycie całkowite (OS, overall survival) po allo-HSCT wynosiło około $68 \% \pm 3 \%$, jednak w analizowanej grupie 211 pacjentów jedynie u $45 \%$ występowała klasyczna postać PNH. Ostra postać GvHD w stopniu II-IV rozwinęła się u 40\% pacjentów, a przewlekłą postać GvHD obserwowano u 29\% pacjentów po 5 latach. Czynnikiem zwiększającym ryzyko zgonu było przebyte zdarzenie zakrzepowo-zatorowe. Całkowite przeżycie 5-letnie w grupie chorych na PNH o klasycznej postaci bez przebytego incydentu zakrzepowo-zatorowego wynosiło 86\% $\pm 6 \%$ [56]. Dyskusyjna pozostaje kwalifikacja do procedury allo-HSCT chorych na PNH o klasycznej postaci, szczególnie w krajach $\mathrm{z}$ nieograniczonym dostępem do ekulizumabu, gdzie allo-HSCT proponuje się tym, u których ekulizumab wykazuje ograniczoną skuteczność albo pojawią się objawy niewydolności lub dysplazji szpiku kostnego. W publikacjach podkreśla się znaczenie procedury allo-HSCT w terapii chorych na PNH o klasycznej postaci w krajach bez dostępu do ekulizumabu [56, 57]. W ostatnich latach pojawiły się doniesienia o skutecznej eradykacji klonu PNH za pomocą kondycjonowania o obniżonej intensywności opartego na fludarabinie [55], z 6-letnim OS na poziomie $87,8 \%$ i niewykrywalnymi granulocytami GPI(-) od 30 . do 150. doby po allo-HSCT (mediana $100 \mathrm{dni}$ ). Może to być opcją u pacjentów $z$ istotnymi chorobami towarzyszącymi, ograniczającymi zastosowanie kondycjonowania mieloablacyjnego, oraz u młodych chorych pragnących zachować możliwości rozrodcze [55, 57, 58]. Z kolei opcją dla pacjentów z PNH kwalifikujących się do procedury allo-HSCT, ale niemających zgodnego dawcy, może być przeprowadzenie transplantacji szpiku od dawcy haploidentycznego $z$ zastosowaniem cyklofosfamidu po przeszczepieniu [59].

\section{Postępowanie w niedokrwistości}

W przypadku niedokrwistości związanej z niewydolnością szpiku kostnego metodą $z$ wyboru pozostaje procedura allo-HSCT. U pacjentów $Z$ wielkością klonu PNH przekraczającą $10 \%$ zazwyczaj występuje klinicznie istotna hemoliza $z$ pobudzeniem erytropoezy, wymagająca terapii wspomagającej, tj. uzupełniania niedoboru kwasu foliowego, niekiedy także witaminy $\mathrm{B}_{12}$ oraz żelaza [5, 13]. Niedobór żelaza wiąże się $z$ jego przewlekłą utratą drogą nerek podczas epizodów hemoglobinurii oraz w wyniku hemosyderynuri. Należy również monitorować stężenie erytropoetyny, szczególnie u chorych na CKD. Zastosowanie glikokortykosteroidów jest dyskusyjne i ogólnie niezalecane, ale istnieją doniesienia o ich skuteczności w ograniczaniu ciężkich przełomów hemolitycznych, co wskazuje na możliwość zahamowania 
któregoś z etapów alternatywnej drogi aktywacji dopełniacza lub pośredniego działania poprzez ograniczenie stanu zapalnego, odpowiedzialnego za zaostrzenie hemolizy. Można więc rozważyć włączenie krótkiego pulsu 0,25-1,0 mg/kg mc. $\mathrm{w}$ przeliczeniu na dawkę prednizonu, jednak ze względu na działanie niepożądane przeciwwskazane jest przedłużone stosowanie [5, 13]. $Z$ kolei w celu kontrolowania przewlekłej hemolizy można rozważyć zastosowanie androgenu, na przykład danazolu (200-400 mg/d.), $z$ monitorowaniem parametrów wątrobowych, jednak $\mathrm{w}$ tym przypadku mechanizm działania nie został wyjaśniony [13].

W przypadku braku dostępu do ekulizumabu objawowa niedokrwistość lub ciężkie zaostrzenie hemolizy są wskazaniem do przetoczenia kkcz. $\mathrm{U}$ pacjentów $z$ klasyczną postacią $\mathrm{PNH}$ nie należy się obawiać poprzetoczeniowej hemosyderozy ze względu na ciągłą utratę żelaza towarzyszącą aktywnej hemolizie wewnątrznaczyniowej. Problem przeładowania żelazem dotyczy natomiast pacjentów z MDS z towarzyszącym klonem PNH $[5,13,52]$.

\section{Hamowanie aktywacji dopełniacza}

Logicznym punktem uchwytu w leczeniu chorych na PNH jest ograniczenie procesu hemolizy wewnątrznaczyniowej indukowanej niekontrolowaną aktywacją dopełniacza i kluczowej dla powikłań występujących w tej jednostce chorobowej. Stało się to możliwe dzięki wprowadzeniu ekulizumabu - przeciwciała anty-C5, który, wiążąc składową C5 dopełniacza, nie dopuszcza do jej rozkładu na C5a i C5b, ograniczając działanie prozapalne i prozakrzepowe oraz blokując kaskadę doprowadzającą do powstania MAC. Tym samym ekulizumab zastępuje niejako funkcję deficytowego, naturalnego regulatora CD59 [60].

W badaniach klinicznych (np. TRIUMPH, SHEPHERD) udowodniono wysoką skuteczność przeciwciała $\mathrm{w}$ ograniczaniu procesu hemolizy i stabilizacji stężenia hemoglobiny, co doprowadziło do rejestracji leku w Stanach Zjednoczonych (FDA, Food and Drug Administration) w marcu 2007 roku, a w Europie w czerwcu 2007 toku (EMA, European Medicines Agency). U chorych, u których stosowano ekulizumab, wykazano zmniejszenie zapotrzebowania na transfuzje $\mathrm{kkcz}$, a także ochronę przed skutkami hemolizy wewnątrznaczyniowej (powikłaniami zakrzepowo-zatorowymi, nadciśnieniem płucnym, pogorszeniem funkcji nerek) oraz istotną poprawę jakości życia [15, 25, 60-64]. Ponadto opublikowano dane wskazujące na brak różnic w przeżyciu chorych na PNH leczonych eku-
Tabela 2. Dawkowanie ekulizumabu w przypadku masy ciała poniżej $40 \mathrm{~kg}$

Table 2. Eculizumab dosing for body weight below $40 \mathrm{~kg}$

\begin{tabular}{lll}
\hline $\begin{array}{l}\text { Masa ciała } \\
{[\mathrm{kg}]}\end{array}$ & $\begin{array}{l}\text { Faza leczenia } \\
\text { początkowego }\end{array}$ & $\begin{array}{l}\text { Faza leczenia } \\
\text { podtrzymującego }\end{array}$ \\
\hline 5 do $<10$ & $\begin{array}{l}300 \mathrm{mg} \\
\text { co tydzień } \times 1\end{array}$ & $\begin{array}{l}300 \mathrm{mg} \text { w } 2 \text {. tygodniu; } \\
\text { następnie } 300 \mathrm{mg} \\
\text { co } 2 \text { tygodnie }\end{array}$ \\
\hline 10 do $<20$ & $\begin{array}{l}600 \mathrm{mg} \\
\text { co tydzień } \times 1\end{array}$ & $\begin{array}{l}300 \mathrm{mg} \text { w } 2 \text {. tygodniu; } \\
\text { następnie } 300 \mathrm{mg} \\
\text { co } 2 \text { tygodnie }\end{array}$ \\
\hline 20 do $<30$ & $\begin{array}{l}600 \mathrm{mg} \\
\text { co tydzień } \times 2\end{array}$ & $\begin{array}{l}600 \mathrm{mg} \mathrm{w} 3 . \text { tygodniu; } \\
\text { następnie } 600 \mathrm{mg} \\
\text { co } 2 \text { tygodnie }\end{array}$ \\
\hline 30 do $<40$ & $\begin{array}{l}600 \mathrm{mg} \\
\text { co tydzień } \times 2\end{array}$ & $\begin{array}{l}900 \mathrm{mg} \text { w 3. tygodniu; } \\
\text { następnie } 900 \mathrm{mg} \\
\text { co } 2 \text { tygodnie }\end{array}$ \\
\hline
\end{tabular}

lizumabem w porównaniu $z$ grupą zdrowych osób, równoważną pod względem wieku i płci $[64,65]$.

Ekulizumab u osób dorosłych i dzieci o masie ciała ponad $40 \mathrm{~kg}$ jest podawany we wlewach dożylnych trwających 25-45 minut w fazie początkowej w dawce $600 \mathrm{mg}$ co tydzień przez pierwsze 4 tygodnie, natomiast $\mathrm{w}$ fazie leczenia podtrzymującego $-900 \mathrm{mg} \mathrm{w} 5$. tygodniu, a następnie co $14 \mathrm{dni}$ ( \pm 2 dni). Dawkowanie u dzieci o masie ciała poniżej $40 \mathrm{~kg}$ podano w tabeli 2 .

Najczęściej raportowanym działaniem niepożądanym leku jest ból głowy, który znacznie się zmniejsza po kilku dawkach i najpewniej wiąże się $z$ gwałtownie wzrastającym stężeniem NO $[12,63]$. Ekulizumab nie upośledza proksymalnego odcinka szlaku aktywacji dopełniacza, zachowana jest więc zdolność do opsonizacji drobnoustrojów chorobotwórczych i eliminacji kompleksów immunologicznych. Należy jednak pamiętać o tym, że poprzez blokowanie odcinka terminalnego szlaku wspólnego dla alternatywnej (CAP, complement alternative pathway) i klasycznej drogi aktywacji dopełniacza (CCP, complement classic pathway) ekulizumab upośledza zdolność eliminacji bakterii otoczkowych zależną od MAC. Ze względu na raportowane zagrażające $\dot{z} y c i u$ infekcje obowiązuje immunizacja czynna pacjenta przeciwko Neisseria meningitidis przynajmniej 2 tygodnie przez podaniem przeciwciała [12,63]. Ze względu na najszersze spektrum i najwyższą immunogenność zaleca się szczepionkę czterowalentną skoniugowaną, zawierającą antygeny serogrup $\mathrm{A}+\mathrm{C}+\mathrm{Y}+\mathrm{W}-135$. W sytuacji pilnych wskazań do włączenia terapii ekulizumabem, na przykład wystąpienia powikłań zakrzepowo-zatorowych, należy 
podać szczepionkę, a do czasu upłynięcia 2 tygodni od immunizacji powinno się stosować profilaktykę antybiotykową ciprofloksacyną [12]. W przypadku występowania przełamujących epizodów hemolizy wewnątrznaczyniowej przed podaniem kolejnej dawki zalecane jest skrócenie odstępu między podaniami o 1-2 dni [12, 63]. Pojedyncze epizody zaostrzenia hemolizy mogą się też wiązać $z$ przejściowym nasileniem aktywacji dopełniacza wywołanej infekcją lub urazem. Po ustąpieniu tego stanu klinicznego aktywność dopełniacza wraca do swojego stałego poziomu i nie jest to wskazaniem do zmiany rytmu podawania ekulizumabu [12].

Przy kwalifikowaniu chorego do leczenia ekulizumabem należy brać pod uwagę przede wszystkim niedokrwistość $(\mathrm{Hb}<10 \mathrm{~g} / \mathrm{dl})$ związaną $\mathrm{z}$ hemolizą i występowanie powikłań zakrzepowo-zatorowych oraz świadomą wolę pacjenta do poddawania się regularnym wlewom leku do końca życia. Pacjent musi zdawać sobie sprawę $z$ tego, że odstąpienie od wlewu w wyznaczonym terminie najpewniej doprowadzi do zaostrzenia hemolizy wewnątrznaczyniowej, której nasilenie zależy od wielkości klonu defektywnych erytrocytów i w następstwie grozi ciężkimi powikłaniami. W przypadku terapii ekulizumabem obowiązuje stosowanie skutecznych metod antykoncepcji. Przy kwalifikacji rekomenduje się uwzględnienie wskaźników wysokiej aktywności hemolizy wewnątrznaczyniowej przekładającej się na wzrost ryzyka powikłań zakrzepowo-zatorowych, której wykładnikami są zwiększona aktywność LDH $(\geq 1,5 \times$ powyżej górnej granicy normy) oraz występowanie hemoglobinurii, duszności, bólu w klatce piersiowej, bólu jamy brzusznej, dysfagii, zaburzeń erekcji i przewlekłego zmęczenia $[5,66]$.

Odpowiedź na ekulizumab jest zmienna i zależy od współwystępującej niewydolności szpiku, infekcji, czynników genetycznych (np. polimorfizmu genu kodującego receptor dopełniacza typu I lub mutacji genu kodującego C5 uniemożliwiających wiązanie ekulizumabu), a także wielkości klonu $z$ defektem typu PNH [12,67]. Ekulizumab nie kompensuje deficytu CD55, dlatego erytrocyty GPI(-) są nadal podatne na opsonizację fragmentami składowej C3 i ich przyspieszoną eliminację $\mathrm{w}$ śledzionie. Tłumaczy to pojawienie się dodatniego BTA (IgG- i C3+) u ponad 50\% leczonych chorych $[12,68]$. Zewnątrznaczyniowa hemoliza może być więc jednym $z$ mechanizmów odpowiedzialnych za utrzymujące się, choć w znacząco zredukowanej częstotliwości, uzależnienie od przetaczania kkcz u około $44 \%$ pacjentów [60, 64, 68]. W badaniach doświadczalnych okazało się, że terapia ekulizumabem odsłania niejako podatność erytrocytów GPI(-) na opsonizację C3, które bez terapii tym przeciwciałem byłyby niszczone w kilka dni poprzez MAC. Prawdopodobnie CD59 ma również znaczenie regulatorowe $\mathrm{w}$ działaniu konwertaz C3, ponieważ izolowany brak CD55 (fenotyp Inab) nie powoduje zwiększonej opsonizacji erytrocytów $[68,69]$.

Lekiem, który ma szansę zrewolucjonizować terapię chorych na PNH, jest rekombinowana fuzyjna cząsteczka białkowa TT30, złożona $z$ fragmentu receptora dopełniacza typu 2 (CR2, complement receptor 2) oraz fragmentu czynnika $\mathrm{H}$ (fH, factor $H)$. Lek ten zaprojektowano tak, aby działał selektywnie w miejscu aktywacji dopełniacza na powierzchni erytrocytów GPI(-) poprzez domenę fragmentu CR2 wiążącą postać nieaktywną C3b/C3dg. $Z$ kolei domena hamująca fH działa wybiórczo na alternatywną drogę aktywacji dopełniacza, bez negatywnego wpływu na aktywność konwertazy C3 powstającej w wyniku pobudzenia CCP i szlaku mannozowo-lektynowego. Czynnik $\mathrm{H}$ zapobiega formowaniu i przyspiesza rozkład konwertazy C3 CAP oraz, działając jako kofaktor czynnika I, pośrednio zapobiega powstawaniu konwertazy C3, zamieniając C3b w postać nieaktywną. W badaniach wykazano skuteczność TT30 w hamowaniu hemolizy wewnątrznaczyniowej oraz zewnątrznaczyniowej zależnej od dopełniacza u chorych na PNH poprzez blokowanie CAP oraz zapobieganie opsonizacji fragmentami C3 [70]. Problemem po zastosowaniu TT30 mogą być epizody hemolizy związane $z$ infekcjami prowadzącymi do aktywacji CCP, szlaku mannozowo-lektynowego i bezpośredniej aktywacji CAP przez lipopolisacharydy bakterii.

\section{Powikłania zakrzepowo-zatorowe — profilaktyka i leczenie}

Wystąpienie zakrzepicy u chorego na PNH wymaga pilnego wdrożenia terapii. Optymalną opcją jest ekulizumab skojarzony $z$ heparyną (w przypadku formy drobnocząsteczkowej z utrzymaniem aktywności anty-Xa 0,5-1,0 jm./ml), z następową terapią antagonistami witaminy $\mathrm{K}$ (VKA, vitamin $K$ antagonist) $\mathrm{w}$ przypadku braku przeciwwskazań [4]. Udowodniono, że ze względu na złożony mechanizm zakrzepowy w PNH w przypadku monoterapii przeciwkrzepliwej mogą wystąpić progresja zakrzepicy, kolejne epizody zakrzepowe i zazwyczaj nie dochodzi do przywrócenia krążenia, na przykład w zespole Budda-Chiariego [20]. W piśmiennictwie są dostępne raporty o skutecznym leczeniu trombolitycznym za pomocą tkankowego aktywatora 
plazminogenu (t-PA, tissue plasminogen activator) sprzed ery ekulizumabu, obarczone jednak dużym ryzykiem powikłań krwotocznych [5, 71]. Istnieją również nieliczne dane dotyczące stosowania nowych doustnych antykoagulantów [72].

W zespole Budda-Chiariego ciężkie przypadki nadciśnienia wrotnego mogą wymagać przezskórnego wszczepienia wewątrzwątrobowego zespolenia wrotno-systemowego, pozwalającego na zmniejszenie objawów. Przed erą ekulizumabu przeszczepienie wątroby było przeciwwskazane, ponieważ kończyło się niepowodzeniem w wyniku nawrotu zakrzepicy, jednak obecnie są doniesienia o sukcesach w tej dziedzinie w przypadku jednoczesnej terapii ekulizumabem [73].

Profilaktyka przeciwkrzepliwa heparyną okazała się skuteczna in vitro oraz in vivo $\mathrm{w}$ zapobieganiu powikłaniom zakrzepowym związanym $z$ aktywacją dopełniacza $\mathrm{w}$ PNH, prawdopodobnie poprzez interakcję z MAC [74]. Istnieją jednak doniesienia o zwiększonym ryzyku rozwoju trombocytopenii indukowanej heparyną (HIT, heparin-induced trombocytopenia) ze względu na zwiększone uwalnianie czynnika tkankowego 4 (PF4, platelet factor 4) z aktywowanych PLT pacjentów z PNH, co powoduje, że stosowanie heparyny w profilaktyce jest ograniczone do sytuacji szczególnych, na przykład okresu ciąży $[5,75]$. W przypadku rozwoju HIT zaleca się fondaparynuks [76]. Nie ma opublikowanych badań dotyczących stosowania w PNH profilaktyki lekami przeciwpłytkowymi (np. kwas acetylosalicylowy, klopidogrel), jednak ze względu na złożony mechanizm powikłań zakrzepowych nie należy się spodziewać wysokiej skuteczności przy jednoczesnym ryzyku powikłań krwotocznych. Profilaktyka za pomocą VKA również nie jest w pełni skuteczna i są liczne doniesienia o epizodach zakrzepowych w przypadku terapeutycznej antykoagulacji. Antykoagulacja $z$ pewnością nie wystarcza we wtórnej profilaktyce po wystąpieniu epizodu zakrzepowo-zatorowego [6, 64, 77].

Zważywszy na zależność stanu trombofilii od składowej C5a i kompleksu C5b-C9, zahamowanie rozkładu składowej C5 za pomocą ekulizumabu wydaje się kluczowe w opanowaniu zaburzeń prozakrzepowych. $\mathrm{W}$ analizie pacjentów poddanych terapii ekulizumabem udowodniono szybkie zmniejszenie liczby mikrocząstek $z \mathrm{TF}$, generacji trombiny, kompleksów trombina-AT oraz plazmina-antyplazmina, IL-6 i markerów aktywacji śródbłonka. Obserwacje te potwierdzono w danych klinicznych z UK National PNH Centre - wykazano obniżenie liczby epizodów zakrzepowych u pacjentów z PNH leczonych ekulizumabem [63, 64].
Pozostaje pytanie, czy skutecznie hamując układ dopełniacza na poziomie składowej C5, można zakończyć profilaktykę przeciwzakrzepową. W przypadku profilaktyki wtórnej wykazano, $\dot{z}$ e należy ją utrzymać, chyba że są ewidentne przeciwwskazania [74]. Opisano natomiast pacjentów, u których $z$ różnych powodów przerwano profilaktykę (zarówno pierwotną, jak i wtórną) w przypadku systematycznego stosowania ekulizumabu i u żadnego $z$ nich nie doszło do epizodu zakrzepowego [63].

Niebezpieczny jest jednak okres po zaprzestaniu wlewów przeciwciała - ze względu na dużą pulę erytrocytów GPI-AP(-) w kilka tygodni dochodzi do gwałtownego nasilenia hemolizy wewnątrznaczyniowej, co wiąże się $z$ bardzo wysokim ryzykiem wystąpienia powikłań zakrzepowych, najczęściej obserwowanych około 8 tygodni po ostatniej dawce. W sytuacji zakończenia terapii ekulizumabem należy więc rozważyć włączenie profilaktyki przeciwzakrzepowej i korygować niedokrwistość przetoczeniami kkcz [63].

\section{Sytuacje szczególne - ciąża}

Ciąża i okres połogu u chorych na PNH wiążą się z pogłębieniem niedokrwistości, ale przede wszystkim ze zwiększonym ryzykiem rozwoju zakrzepicy. Decyzja o posiadaniu potomstwa powinna być dobrze przemyślana. Cały okres ciąży i połogu wymaga stosowania heparyny drobnocząsteczkowej z monitorowaniem aktywności anty-Xa, korygowania niedokrwistości za pomocą przetoczeń kkcz i uzupełniania niedoboru żelaza. Istnieją opisy prawidłowo przebiegających ciąż w przypadku takiego postępowania [5]. Zgodnie z zapisem rejestracyjnym zaleca się stosowanie antykoncepcji podczas terapii ekulizumabem. Podawanie ekulizumabu chorej w ciąży ma uzasadnienie, jeżeli „potencjalne korzyści przewyższają ryzyko”. W wielu ośrodkach, których personel ma doświadczenie ze stosowaniem ekulizumabu, podjęto decyzję o kontynuowaniu terapii podczas okresu poczęcia, ciąży i połogu. Ekulizumab okazał się korzystnym rozwiązaniem i w większości przypadków ciąże przebiegały bez powikłań. Niektóre kobiety wymagały zwiększenia dawki lub częstości podawania leku [78, 79].

\section{Podsumowanie}

Nocna napadowa hemoglobinuria jest chorobą o różnorodnej manifestacji klinicznej, jednak świadomość kluczowych zaburzeń i powikłań z nią 
związanych z pewnością umożliwi szybsze wdrożenie odpowiedniego postępowania, które ma szansę uchronić chorego przed skutkami prowadzącymi do przedwczesnego zgonu. Kluczowym elementem terapii jest ingerencja w układ dopełniacza, która przerywa „błędne koło” nieprawidłowości i ogranicza dolegliwości związane z przewlekłą hemolizą. Co najważniejsze, jest najlepszą profilaktyką przeciwzakrzepową i pozwala opanować ostre epizody zakrzepowo-zatorowe. Istnieją już dane wskazujące na brak różnic w przeżyciu chorych na PNH leczonych ekulizumabem $w$ porównaniu $z$ grupą osób zdrowych równoważną pod względem wieku i płci. W przypadku braku możliwości stosowania ekulizumabu należy rozważyć przeprowadzenie allo-HSCT, które jako jedyna metoda może prowadzić do wyleczenia, jest jednak obarczona ryzykiem poważnych powikłań i zgonu. Ze względu na rzadkość choroby i złożoność powikłań $z$ nią związanych $\mathrm{w}$ każdym kraju powstają ośrodki referencyjne, które pełnią funkcję doradczą w skomplikowanych sytuacjach klinicznych. Zainteresowanych autorki odsyłają na www.pnhregistry.com.

\section{Piśmiennictwo}

1. Borowitz M.J., Craig F.E., Digiuseppe J.A. i wsp. Guidelines for the diagnosis and monitoring of paroxysmal nocturnal hemoglobinuria and related disorders by flow cytometry. Cytometry B Clin. Cytom. 2010; 78: 211-230.

2. Socie G., Mary J.Y., de G.A. i wsp. Paroxysmal nocturnal haemoglobinuria: long-term follow-up and prognostic factors. French Society of Haematology. Lancet 1996; 348: 573-577.

3. Hillmen P., Lewis S.M., Bessler M., Luzzatto L., Dacie J.V. Natural history of paroxysmal nocturnal hemoglobinuria. N. Engl. J. Med. 1995; 333: 1253-1258.

4. Hill A., Kelly R.J., Hillmen P. Thrombosis in paroxysmal nocturnal hemoglobinuria. Blood 2013; 121: 4985-4996.

5. Luzzatto L., Gianfaldoni G., Notaro R. Management of paroxysmal nocturnal haemoglobinuria: a personal view. Br. J. Haematol. 2011; 153: 709-720.

6. de Latour R.P., Mary J.Y., Salanoubat C. i wsp. Paroxysmal nocturnal hemoglobinuria: natural history of disease subcategories. Blood 2008; 112: 3099-3106.

7. Brodsky R.A., Hu R. PIG-A mutations in paroxysmal nocturnal hemoglobinuria and in normal hematopoiesis. Leuk. Lymphoma 2006; 47: 1215-1221.

8. Brodsky R.A. Narrative review: paroxysmal nocturnal hemoglobinuria: the physiology of complement-related hemolytic anemia. Ann. Intern. Med. 2008; 148: 587-595.

9. Nafa K., Bessler M., Castro-Malaspina H., Jhanwar S., Luzzatto L. The spectrum of somatic mutations in the PIG-A gene in paroxysmal nocturnal hemoglobinuria includes large deletions and small duplications. Blood Cells Mol. Dis. 1998; 24: 370-384.

10. Luzzatto L. PNH from mutations of another PIG gene. Blood 2013; 122: 1099-1100.
11. Loveland B.E., Szokolai K., Johnstone R.W., McKenzie I.F. Coordinate functions of multiple complement regulating molecules, CD46, CD55, and CD59. Transplant Proc. 1994; 26: 1070-1071.

12. Brodsky R.A. Paroxysmal nocturnal hemoglobinuria. Blood 2014; 124: 2804-2811.

13. Parker C., Omine M., Richards S. i wsp. Diagnosis and management of paroxysmal nocturnal hemoglobinuria. Blood 2005; 106: 3699-3709.

14. Misztal T., Tomasiak M. [Pathophysiological consequences of hemolysis. Role of cell-free hemoglobin]. Postepy Hig. Med. Dosw. (Online) 2011; 65: 627-639.

15. Hill A., Rother R.P., Wang X. i wsp. Effect of eculizumab on haemolysis-associated nitric oxide depletion, dyspnoea, and measures of pulmonary hypertension in patients with paroxysmal nocturnal haemoglobinuria. Br. J. Haematol. 2010; 149: 414-425.

16. Nishimura J., Kanakura Y., Ware R.E. i wsp. Clinical course and flow cytometric analysis of paroxysmal nocturnal hemoglobinuria in the United States and Japan. Medicine (Baltimore) 2004; 83: 193-207.

17. Hill A., Sapsford R.J., Scally A. i wsp. Under-recognized complications in patients with paroxysmal nocturnal haemoglobinuria: raised pulmonary pressure and reduced right ventricular function. Br. J. Haematol. 2012; 158: 409-414.

18. Schrezenmeier H., Muus P., Socie G. i wsp. Baseline characteristics and disease burden in patients in the International Paroxysmal Nocturnal Hemoglobinuria Registry. Haematologica 2014; 99: 922-929.

19. Meppiel E., Crassard I., Peffault de L.R. i wsp. Cerebral venous thrombosis in paroxysmal nocturnal hemoglobinuria: a series of 15 cases and review of the literature. Medicine (Baltimore) 2015; 94: e362.

20. Hoekstra J., Leebeek F.W., Plessier A. i wsp. Paroxysmal nocturnal hemoglobinuria in Budd-Chiari syndrome: findings from a cohort study. J. Hepatol. 2009; 51: 696-706.

21. Poulou L.S., Vakrinos G., Pomoni A. i wsp. Stroke in paroxysmal nocturnal haemoglobinuria: patterns of disease and outcome. Thromb. Haemost. 2007; 98: 699-701.

22. Watt S.G., Winhoven S., Hay C.R., Lucas G.S. Purpura fulminans in paroxysmal nocturnal haemoglobinuria. Br. J. Haematol. 2007; 137: 271

23. Ninomiya H., Kawashima Y., Hasegawa Y., Nagasawa T. Complement-induced procoagulant alteration of red blood cell membranes with microvesicle formation in paroxysmal nocturnal haemoglobinuria (PNH): implication for thrombogenesis in PNH. Br. J. Haematol. 1999; 106: 224-231.

24. Huber-Lang M., Sarma J.V., Zetoune F.S. i wsp. Generation of C5a in the absence of $\mathrm{C} 3$ : a new complement activation pathway. Nat. Med. 2006; 12: 682-687.

25. Hillmen P., Elebute M., Kelly R. i wsp. Long-term effect of the complement inhibitor eculizumab on kidney function in patients with paroxysmal nocturnal hemoglobinuria. Am. J. Hematol. 2010; 85: 553-559.

26. Rother R.P., Bell L., Hillmen P., Gladwin M.T. The clinical sequelae of intravascular hemolysis and extracellular plasma hemoglobin: a novel mechanism of human disease. JAMA 2005; 293: 1653-1662.

27. Spychalska J., Brojer E. Nocna napadowa hemoglobinuria patofizjologia, klasyfikacja i nowoczesna diagnostyka. Hematologia 2013; 4: 301-320.

28. Pu J.J., Mukhina G., Wang H., Savage W.J., Brodsky R.A. Natural history of paroxysmal nocturnal hemoglobinuria clones in patients presenting as aplastic anemia. Eur. J. Haematol. 2011; 87: 37-45. 
29. Kulagin A., Lisukov I., Ivanova M. i wsp. Prognostic value of paroxysmal nocturnal haemoglobinuria clone presence in aplastic anaemia patients treated with combined immunosuppression: results of two-centre prospective study. Br. J. Haematol. 2014; 164: 546-554.

30. Araten D.J., Bessler M., McKenzie S. i wsp. Dynamics of hematopoiesis in paroxysmal nocturnal hemoglobinuria (PNH): no evidence for intrinsic growth advantage of PNH clones. Leukemia 2002; 16: 2243-2248.

31. Luzzatto L., Bessler M., Rotoli B. Somatic mutations in paroxysmal nocturnal hemoglobinuria: a blessing in disguise? Cell 1997; 88: $1-4$.

32. Pu J.J., Hu R., Mukhina G.L. i wsp. The small population of PIG-A mutant cells in myelodysplastic syndromes do not arise from multipotent hematopoietic stem cells. Haematologica 2012; 97: 1225-1233.

33. Traulsen A., Pacheco J.M., Luzzatto L., Dingli D. Somatic mutations and the hierarchy of hematopoiesis. Bioessays 2010; 32 : 1003-1008.

34. Savage W.J., Barber J.P., Mukhina G.L. i wsp. Glycosylphosphatidylinositol-anchored protein deficiency confers resistance to apoptosis in PNH. Exp. Hematol. 2009; 37: 42-51.

35. Karadimitris A., Notaro R., Koehne G., Roberts I.A., Luzzatto L. PNH cells are as sensitive to T-cell-mediated lysis as their normal counterparts: implications for the pathogenesis of paroxysmal nocturnal haemoglobinuria. Br. J. Haematol. 2000; 111: 1158-1163.

36. Shen W., Clemente M.J., Hosono N. i wsp. Deep sequencing reveals stepwise mutation acquisition in paroxysmal nocturnal hemoglobinuria. J. Clin. Invest. 2014; 124: 4529-4538.

37. Dingli D., Luzzatto L., Pacheco J.M. Neutral evolution in paroxysmal nocturnal hemoglobinuria. Proc. Natl. Acad. Sci. USA 2008; 105: 18496-18500.

38. Brodsky R.A. How do PIG-A mutant paroxysmal nocturnal hemoglobinuria stem cells achieve clonal dominance? Expert Rev. Hematol. 2009; 2: 353-356.

39. Ratajczak J., Kucia M., Mierzejewska K. i wsp. A novel view of paroxysmal nocturnal hemoglobinuria pathogenesis: more motile PNH hematopoietic stem/progenitor cells displace normal HSPCs from their niches in bone marrow due to defective adhesion, enhanced migration and mobilization in response to erythrocyte-released sphingosine-1 phosphate gradient. Leukemia 2012; 26 : 1722-1725.

40. Ratajczak M.Z., Kim C.H., Wojakowski W. i wsp. Innate immunity as orchestrator of stem cell mobilization. Leukemia 2010; 24: 1667-1675.

41. Raza A., Ravandi F., Rastogi A. i wsp. A prospective multicenter study of paroxysmal nocturnal hemoglobinuria cells in patients with bone marrow failure. Cytometry B Clin. Cytom. 2014; 86: 175-182.

42. Richards S.J., Whitby L., Cullen M.J. i wsp. Development and evaluation of a stabilized whole-blood preparation as a process control material for screening of paroxysmal nocturnal hemoglobinuria by flow cytometry. Cytometry B Clin. Cytom. 2009; 76: 47-55

43. Brodsky R.A., Mukhina G.L., Li S. i wsp. Improved detection and characterization of paroxysmal nocturnal hemoglobinuria using fluorescent aerolysin. Am. J. Clin. Pathol. 2000; 114: 459-466.

44. Peghini P.E., Fehr J. Clinical evaluation of an aerolysin-based screening test for paroxysmal nocturnal haemoglobinuria. Cytometry B Clin. Cytom. 2005; 67: 13-18.
45. Spychalska J., Żupańska B., Błocka M., Pyl A., Brojer E. Unowocześnie diagnostyki nocnej napadowej hemoglobinurii - wstępne wyniki badań przy użyciu odczynnika FLAER. Acta Haematol. Pol. 2012; 43: 285-290.

46. Marinov I., Kohoutova M., Tkacova V. i wsp. Intra- and interlaboratory variability of paroxysmal nocturnal hemoglobinuria testing by flow cytometry following the 2012 practical guidelines for high-sensitivity paroxysmal nocturnal hemoglobinuria testing. Cytometry B Clin. Cytom. 2013; 84: 229-236.

47. Sutherland D.R., Keeney M., Illingworth A. Practical guidelines for the high-sensitivity detection and monitoring of paroxysmal nocturnal hemoglobinuria clones by flow cytometry. Cytometry B Clin. Cytom. 2012;82:195-208.

48. Marinov I., Kohoutova M., Tkacova V. i wsp. Clinical relevance of CD157 for rapid and cost-effective simultaneous evaluation of PNH granulocytes and monocytes by flow cytometry. Int. J. Lab. Hematol. 2015; 37: 231-237.

49. Sutherland D.R., Acton E., Keeney M., Davis B.H., Illingworth A. Use of CD157 in FLAER-based assays for high-sensitivity PNH granulocyte and $\mathrm{PNH}$ monocyte detection. Cytometry B Clin. Cytom. 2014; 86: 44-55.

50. Sutherland D.R., Kuek N., Azcona-Olivera J. i wsp. Use of a FLAER-based WBC assay in the primary screening of PNH clones. Am. J. Clin. Pathol. 2009; 132: 564-572.

51. Zupańska B., Spychalska J., Pyl A., Mendek-Czajkowska E., Brojer E. Nocna napadowa hemoglobinuria - wieloletnie obserwacje. Charakterystyka kliniczna i analiza wielkości klonu z defektem kotwicy glikozylofosfatydyloinozytolowej (GPI). Acta Haematol. Pol. 2012; 43: 75-82.

52. Brodsky R.A. How I treat paroxysmal nocturnal hemoglobinuria. Blood 2009; 113: 6522-6527.

53. Scheinberg P., Young N.S. How I treat acquired aplastic anemia. Blood 2012; 120: 1185-1196.

54. Bacigalupo A., Socie G., Schrezenmeier H. i wsp. Bone marrow versus peripheral blood as the stem cell source for sibling transplants in acquired aplastic anemia: survival advantage for bone marrow in all age groups. Haematologica 2012; 97 : 1142-1148.

55. Pantin J., Tian X., Geller N. i wsp. Long-term outcome of fludarabine-based reduced-intensity allogeneic hematopoietic cell transplantation for debilitating paroxysmal nocturnal hemoglobinuria. Biol. Blood Marrow Transplant. 2014; 20: 1435-1439.

56. Peffault de L.R., Schrezenmeier H., Bacigalupo A. i wsp. Allogeneic stem cell transplantation in paroxysmal nocturnal hemoglobinuria. Haematologica 2012; 97: 1666-1673.

57. Brodsky R.A. Stem cell transplantation for paroxysmal nocturnal hemoglobinuria. Haematologica 2010; 95: 855-856.

58. Suenaga K., Kanda Y., Niiya H. i wsp. Successful application of nonmyeloablative transplantation for paroxysmal nocturnal hemoglobinuria. Exp. Hematol. 2001; 29: 639-642.

59. Brodsky R.A., Luznik L., Bolanos-Meade J. i wsp. Reduced intensity HLA-haploidentical BMT with post transplantation cyclophosphamide in nonmalignant hematologic diseases. Bone Marrow Transplant. 2008; 42: 523-527.

60. Hillmen P., Young N.S., Schubert J. i wsp. The complement inhibitor eculizumab in paroxysmal nocturnal hemoglobinuria. N. Engl. J. Med. 2006; 355: 1233-1243.

61. Hill A., Rother R.P., Hillmen P. Improvement in the symptoms of smooth muscle dystonia during eculizumab therapy in paroxysmal nocturnal hemoglobinuria. Haematologica 2005; 90: ECR40. 


\section{Hematologia 2015, tom 6, nr 3}

62. Hillmen P., Muus P., Duhrsen U. i wsp. Effect of the complement inhibitor eculizumab on thromboembolism in patients with paroxysmal nocturnal hemoglobinuria. Blood 2007; 110: 4123-4128.

63. Hillmen P., Muus P., Roth A. i wsp. Long-term safety and efficacy of sustained eculizumab treatment in patients with paroxysmal nocturnal haemoglobinuria. Br. J. Haematol. 2013; 162: 62-73.

64. Kelly R.J., Hill A., Arnold L.M. i wsp. Long-term treatment with eculizumab in paroxysmal nocturnal hemoglobinuria: sustained efficacy and improved survival. Blood 2011; 117: 6786-6792.

65. Luzzatto L., Risitano A.M., Notaro R. Paroxysmal nocturnal hemoglobinuria and eculizumab. Haematologica 2010; 95: 523-526.

66. Lee J.W., Jang J.H., Kim J.S. i wsp. Clinical signs and symptoms associated with increased risk for thrombosis in patients with paroxysmal nocturnal hemoglobinuria from a Korean Registry. Int. J. Hematol. 2013;97:749-757.

67. DeZern A.E., Dorr D., Brodsky R.A. Predictors of hemoglobin response to eculizumab therapy in paroxysmal nocturnal hemoglobinuria. Eur. J. Haematol. 2013; 90: 16-24.

68. Hill A., Rother R.P., Arnold L. i wsp. Eculizumab prevents intravascular hemolysis in patients with paroxysmal nocturnal hemoglobinuria and unmasks low-level extravascular hemolysis occurring through C3 opsonization. Haematologica 2010; 95: 567-573.

69. Holguin M.H., Martin C.B., Bernshaw N.J., Parker C.J. Analysis of the effects of activation of the alternative pathway of complement on erythrocytes with an isolated deficiency of decay accelerating factor. J. Immunol. 1992; 148: 498-502.

70. Risitano A.M., Notaro R., Pascariello C. i wsp. The complement receptor $2 /$ factor $\mathrm{H}$ fusion protein TT30 protects paroxysmal nocturnal hemoglobinuria erythrocytes from complement-mediated hemolysis and C3 fragment. Blood 2012; 119: 6307-6316.
71. Araten D.J., Notaro R., Thaler H.T. i wsp. Thrombolytic therapy is effective in paroxysmal nocturnal hemoglobinuria: a series of nine patients and a review of the literature. Haematologica 2012; 97:344-352.

72. Paikin J.S., Eikelboom J.W., Cairns J.A., Hirsh J. New antithrombotic agents - insights from clinical trials. Nat. Rev. Cardiol. 2010; 7: 498-509.

73. Singer A.L., Locke J.E., Stewart Z.A. i wsp. Successful liver transplantation for Budd-Chiari syndrome in a patient with paroxysmal nocturnal hemoglobinuria treated with the anti-complement antibody eculizumab. Liver Transpl. 2009; 15: 540-543.

74. Ninomiya H., Kawashima Y., Nagasawa T. Inhibition of complement-mediated haemolysis in paroxysmal nocturnal haemoglobinuria by heparin or low-molecular weight heparin. Br. J. Haematol. 2000; 109: 875-881.

75. Araten D.J., Notaro R., Thaler H.T. i wsp. Thrombolytic therapy is effective in paroxysmal nocturnal hemoglobinuria: a series of nine patients and a review of the literature. Haematologica 2012; 97:344-352.

76. D‘Amico E.A., Villaca P.R., Gualandro S.F., Bassitt R.P., Chamone D.A. Successful use of Arixtra in a patient with paroxysmal nocturnal hemoglobinuria, Budd-Chiari syndrome and heparin-induced thrombocytopenia. J. Thromb. Haemost. 2003; 1: 2452-2453.

77. Moyo V.M., Mukhina G.L., Garrett E.S., Brodsky R.A. Natural history of paroxysmal nocturnal haemoglobinuria using modern diagnostic assays. Br. J. Haematol. 2004; 126: 133-138.

78. Kelly R., Arnold L., Richards S. i wsp. The management of pregnancy in paroxysmal nocturnal haemoglobinuria on long term eculizumab. Br. J. Haematol. 2010; 149: 446-450.

79. Kelly R.J., Hochsmann B., Szer J. i wsp. Eculizumab in pregnant patients with paroxysmal nocturnal hemoglobinuria. N. Engl. J. Med. 2015; 373: 1032-1039. 